\title{
Long-term mechanical behavior of aramid fibers in seawater
}

\author{
G. Derombise ${ }^{1}$, E. Chailleux ${ }^{2, *}$, B. Forest ${ }^{3}$, L. Riou ${ }^{3}$, N. Lacotte ${ }^{3}$, L. Vouyovitch Van Schoors ${ }^{1}$, \\ P. Davies ${ }^{3}$ \\ ${ }^{1}$ Division for Material Physicochemistry, Laboratoire Central des Ponts et Chaussées, Paris, France \\ ${ }^{2}$ Division Structures et Matériaux pour les Infrastructures de Transport, Laboratoire Central des Ponts et \\ Chaussées, Bouguenais, France \\ ${ }^{3}$ Materials and Structures Group, IFREMER (French Ocean Research Institute), Brest, France \\ *: Corresponding author : Emmanuel Chailleux, email address : emmanuel.chailleux@lcpc.fr
}

\begin{abstract}
:
Aramid fibers are today proposed in ropes and cables for marine applications. As these highly crystalline materials are loaded in tension for a longer period in seawater, their long-term mechanical behavior has to be understood. However, the response is time-dependent and exhibits a nonlinear effect with stress. In this study, two types of aramid fibers are studied: Twaron and Technora. Mechanical properties are measured using static tensile tests and creep-recovery tests. A nonlinear viscoelastic-viscoplastic model, based on the Schapery formulation, allows discriminating between the instantaneous and the time-dependent response as well as the reversible and nonreversible phenomena (plasticity). First, this procedure allows the overall mechanical behavior of the fibers to be compared, considering creep rate, plasticity, and instantaneous moduli. Then, using these parameters, the effect of the testing condition, air or seawater is studied. Finally, the effect of aging in seawater is quantified for both fibers.
\end{abstract}




\section{Introduction}

High performance ropes and wires based on aramid fibers have been used for over thirty years for marine applications such as handling lines, buoy and scientific instrument mooring lines, pendant lines on drilling platforms, etc [1]. Their high specific tensile properties and excellent chemical resistance make them a serious competitor to steel wires. However the taut leg configuration rather than the catenary form commonly employed for steel cables, requires careful consideration to be given to the behavior of these materials under static and cyclic loads over long periods.

Two types of aramid fibers which can be used for marine applications are the Twaron and Technora grades, both produced by Teijin Aramid. The Twaron fibers are based on poly $(p-$ phenylene terephthalamide), whereas the Technora fibers are based on copoly(paraphenylene/3,4'-oxydiphenylene terephthalamide) (Figure 1) [2, 3].

Both fibers exhibit a highly crystalline and highly anisotropic structure which has been described extensively by several authors [4-9]. In spite of their highly oriented molecular structure, creep and recovery cannot be ignored when long lengths are subjected to longterm loading (20 years or more for a floating offshore platform which may be moored in 3 kilometres water depth).

Northolt and colleagues [10-13] studied the deformation mechanism in tension of aramid fibers. The authors suggested that the overall strain results from the rotation and elongation of the crystallites. They showed that the crystallite elongation is purely elastic whereas the crystallite rotation is composed of a reversible and an irreversible part. The non-linear behavior of aramid fibers is illustrated by the stress-strain curve (accompanied by a modulusstrain curve) displayed in Figure 2.

It may be noticed that the tensile curves deviates from linearity. Indeed, the modulus curve of Twaron 1000 fibers first decreases with strain to a minimum located around $0.5 \%$ strain, then increases up to the tensile break.

Baltussen and Northolt [14] showed that both the non-linear viscoelastic and viscoplastic deformation must be taken into account in order to model creep of PPTA fibers correctly.

The non-linear viscoelastic and viscoplastic behavior of Twaron 1000 yarns has been successfully modelled by Chailleux and Davies [15]. Based on Northolt and colleagues' work on the deformation behavior of aramid fibers $[11,12,16]$ the authors divided the total strain into a reversible part, related to the non-linear viscoelastic behavior, and a non-reversible viscoplastic part, as follows:

$$
\varepsilon(t, \sigma)=\varepsilon_{n l v e}(t)+\varepsilon_{v p}(t)
$$

For the non-linear viscoelasticity, they applied the approach developed by Schapery $[17,18]$. The viscoplastic component was expressed using Perzyna's approach [19]. Considering the expressions for the creep rate proposed by Baltussen and Northolt [16] and by Lafitte and Bunsell [20], the authors expressed the creep strain $\varepsilon_{c}(t)$ at a given stress $\sigma_{c}$ as function of time:

$$
\varepsilon_{c}(t)=g_{0} D_{0} \sigma_{c}+g_{1} g_{2} \sigma_{c} D_{1} \log _{10}\left(\frac{t}{a_{\sigma}}+1\right)+\sigma_{c}\left(m+D_{p} \log _{10}(t+1)\right)
$$

In this expression, $D_{0}$ is the instantaneous creep compliance. The non-linear parameters $g_{0}$, $g_{1}, g_{2}$ and $a_{\sigma}$ depend on the stress. $D_{1}$ corresponds to the creep rate, $m$ is the 
instantaneous component of the irreversible strain and $D_{p}$ corresponds to the plastic strain rate.

The relation used by Lai and Bakker [21]: $\varepsilon_{c r}=\varepsilon_{c}\left(t_{1}\right)-\varepsilon_{r}(t)$, was applied to eliminate the plastic strain component. $\varepsilon_{c r}$ can be thus expressed as follows :

$$
\varepsilon_{c r}(t)=g_{0} D_{0} \sigma_{c}+g_{2} D_{1} \sigma_{c}\left[g_{1} \log _{10}\left(\frac{t}{a_{\sigma}}+1\right)+\log _{10}\left(t-t_{1}+1\right)-\log _{10}\left(\frac{t_{1}}{a_{\sigma}}+t-t_{1}+1\right)\right]
$$

Chailleux and Davies determined the parameters in Equations (2) and (3) from creeprecovery tests. An example of a creep-recovery curve, representing the evolution of the creep strain $\varepsilon_{c}(t)$ and the recovery strain $\varepsilon_{r}(t)$ as function of time, is displayed in Figure 3.

The authors developed an experimental set-up to measure the creep and recovery strains using a laser transducer [15]. They suspended $2500 \mathrm{~mm}$-long Twaron 1000 yarns and fixed a support to the lower end to take the weights (up to $50 \%$ of the ultimate tensile strength). They determined the parameters by fitting the theoretical curves to the experimental data of $\varepsilon_{c r}(t)$ and $\varepsilon_{c}(t)$. The model developed by Chailleux and Davies provides a tool capable of predicting the strain response under any complex loading sequence in air.

After a comparison of the viscoelastic and viscoplastic behavior and the tensile properties of two types of aramid fibers, namely Twaron 1000 and Technora T200w fibers, two aspects will be examined in this study. First, the influence of test conditions will be studied, in order to establish whether performing the testing of new yarns immersed in seawater results in different results to those from tests in air. Then, the influence of aging will be studied, by performing the same tests on yarns which had previously been subjected to a prolonged immersion in seawater. These aspects are of considerable importance for marine applications of aramid cables and ropes, as very few data are currently available to allow their long-term behavior to be predicted.

\section{Experimental}

\subsection{Materials}

Two types of aramid fibers, used for cables and ropes in marine applications, were studied here: Twaron 1000 and Technora T200w fibers, both produced by Teijin Aramid. The Twaron 1000 fiber, in the form of 1680 dtex yarns, is based on poly(p-phenylene terephthalamide) (PPTA). This fiber contains 0.6 to $1 \mathrm{wt} \%$ of finish. The Technora T200w fiber, in the form of 1670 dtex yarns, is based on copoly( $p$-phenylene/3,4'-diphenyl ether terephthalamide). This fiber contains 10 to $12 \mathrm{wt} \%$ of a "marine finish" aiming at improving bending fatigue in wet applications. Some results for Twaron 1010 and Technora T000 grade fibers, with very low finish levels, are also discussed as these were used to calibrate the FTIR study.

\subsection{Aging methods}

Yarn samples were immersed in natural seawater for up to one and half years. The seawater was taken directly from the Brest estuary and filtered to remove biological activity. The seawater was circulating and continuously renewed. Its $\mathrm{pH}$ value was measured to be between 8.04 and 8.57 (at $\sim 14^{\circ} \mathrm{C}$ ); salt concentration is $32.8-33.4 \mathrm{~g} / \mathrm{L}$. A range of aging temperatures was studied but results for two will be discussed in this paper: 20 and $80^{\circ} \mathrm{C}$. 
Over the aging period considered here the temperature variability is estimated at $\pm 2^{\circ} \mathrm{C}$. The temperature controlled circulating seawater tanks are presented in Figure 4.

\subsection{Fourier Transformed Infrared analysis}

FTIR analysis was performed in the Attenuated Total Reflectance (ATR) mode with a Nicolet Impact 410 spectrometer and Durascope Diamond ATR equipment. The spectra were recorded with a resolution of $2 \mathrm{~cm}^{-1}$, and an accumulation of 32 spectra. The spectra were analysed with OMNIC 3.1 software. Each scan was made with a yarn, composed of 1000 filaments, and repeated three times per sample. The aim of this analysis was to follow the normalised intensity of a peak related to the finish.

Semi-quantitative analysis was thus performed after identifying several peaks, as described elsewhere [22-24]:

- For Twaron 1000 fibers, the peak located at $1109 \mathrm{~cm}^{-1}$ has been attributed to the finish, by comparison with the Twaron 1010 fibers which have a lower finish amount $(0.14 \mathrm{wt} \%$ of finish). The peak height was normalised using the peak located at $\sim 820 \mathrm{~cm}^{-1}$ assigned to the $\mathrm{C}-\mathrm{H}$ deformation of aromatic rings, for which the intensity appears to be constant throughout the aging duration. A FTIR spectrum of Twaron 1000 fibers is presented on Figure 5.

- For Technora T200w fibers, the peak located at $2916 \mathrm{~cm}^{-1}$ has been attributed to the finish, by comparison with the Technora T000 fibers which does not contain any finish. The peak height was normalised using the peak located at $-820 \mathrm{~cm}^{-1}$ assigned to the $\mathrm{C}-\mathrm{H}$ deformation of aromatic rings, for which the intensity appears to be constant throughout the aging duration. A FTIR spectrum of Technora T200w fibers is presented on Figure 6.

\subsection{Static tensile tests}

The tensile tests were carried out on both single fibers and on yarns.

The tensile tests on single fibers were performed using a Zwick 1474 tensile testing machine with a $5 \mathrm{~N}$ load cell and a rate of extension of $10 \%$ of gauge length/min, at $20^{\circ} \mathrm{C}$. The fiber diameter was measured before each test using a laser micrometer Mitutoyo LSM-500S mounted on the tensile testing machine. The precision of the laser micrometer is $\pm 0.1 \mu \mathrm{m}$. Around fifteen valid measurements were considered for each sample.

The tensile tests on yarns were performed using an Instron 5566 tensile testing machine with a $500 \mathrm{~N}$ load cell, at $20 \pm 2^{\circ} \mathrm{C}$ and $50 \pm 5 \%$ relative humidity. The gauge length (yarn length measured between the tensile clamps) was $\sim 500 \mathrm{~mm}$ and the strain rate was $50 \mathrm{~mm} / \mathrm{min}$.

\subsection{Characterization of the viscoelastic and viscoplastic behavior}

\subsubsection{Creep-recovery system}

In a previous study [15] the creep-recovery data were measured on yarns suspended vertically, to which weights were attached manually. This system was not suitable for wet tests so a horizontal test bed was designed and built, Figure 7 . In the initial version, used for tests in air described here and some seawater immersions, loads were again applied manually by deadweights. However, this requires an operator to be present at precise times during the 8-hour test cycle. An automated loading system was therefore developed, based on a servo-controlled electric motor and a PC which activated the motor when the measured 
load varied by a pre-determined amount from the required load. Two digital cameras above the test bed record the movements of two markers, fixed to the central portion of the yarn, continuously, together with the load. The cameras are calibrated at the start of each test in order to determine the pixel/mm factor. The height of each camera can be adjusted to optimise this. An image correlation programme, developed in-house using Matlab ${ }^{\mathrm{TM}}$ software, transforms the displacements into strain using the initial distance between the markers (typically 1.5 meters).

\subsubsection{Creep-recovery sequence}

Based on Northolt et al.'s study [12], Chailleux and Davies showed, from a complex creeprecovery sequence, that the residual strain of Twaron 1000 yarn accumulates when the load increases and remains constant when the yarn is loaded to a load below that encountered previously. They determined thus the viscoelastic and viscoplastic parameters from creeprecovery tests using six increasing stress levels (up to 50\% of the ultimate tensile strength). Here, it is assumed that the mechanical history is erased when the fiber is loaded at a level which is superior to the previous maximum loading.

In this study, we have chosen a sequence composed of six increasing stress levels representing 20 to $60 \%$ of the ultimate tensile strength (UTS) for Twaron 1000 yarns and 17 to $52 \%$ of the UTS for Technora T200w yarns, Figure 8. Each creep and recovery period lasts approximately 40 minutes.

\subsubsection{Identification of the model parameters}

The parameters are obtained by fitting the theoretical curves to the experimental data of $\varepsilon_{c r}(t)$ and $\varepsilon_{c}(t)[15]$. Fitting is performed using unconstrained non-linear optimisation algorithms in the least square sense. First, a simplex method is used in order to approach the solution. Then, refined results are determined using an interior-reflective Newton method. This is programmed using Matlab ${ }^{T M}$ software.

The multi-variable optimisation is first performed on the parameters concerning $\varepsilon_{c r}(t)$, i.e. $g_{0} D_{0}, g_{2} D_{1}, a_{\sigma}$ and $g_{1}$. Then taking into account the results of this first step, the optimisation procedure is applied to the parameters of the plastic strain component concerning $\varepsilon_{c}(t)$. This method enables the viscoelastic and viscoplastic parameters to be determined independently. Also, the parameters $a_{\sigma}$ and $g_{1}$ were found to be independent of the load. The optimisation was therefore performed for $a_{\sigma}=1$ and $g_{1}=1$.

Four parameters are thus evaluated here: the instantaneous compliance $g_{0} D_{0}$, the creep rate $g_{2} D_{1}$, the instantaneous plasticity $m$, and the plastic rate $D_{p}$. In a creep-recovery experiment, these parameters can be linked to the material response as shown on Figure 9.

It must be noted that the parameter $D_{p}$ was always found to be negligible. So, plasticity phenomenon occurs only instantaneously. This latter parameter will thus not be discussed in the following sections. 


\subsubsection{Test conditions}

The different creep-recovery test conditions are summarized in Table 1.

\section{Results and discussion}

\subsection{Static tensile properties}

\subsubsection{Twaron 1000 fibers aged in seawater}

The tensile properties of Twaron 1000 fibers before and after one and half years aging in seawater at $20^{\circ} \mathrm{C}$ are grouped in Table 2 .

The single fiber tests are performed on samples bonded to metal plates so there is no end movement of fibers, whereas the static yarn tests use rounded pneumatic grips. Single fiber strengths are significantly higher than those measured on yarns, for which it is difficult to ensure a uniform loading over all fibers. Indeed, the ultimate tensile strength of single fibers remains constant after one and half years aging in seawater at $20^{\circ} \mathrm{C}$ whereas it decreases by $\sim 21 \%$ at the yarn scale.

The tangent modulus increases with the stress for both kind of tensile tests, as shown previously elsewhere [12]. However, considering the tensile tests performed on yarns, a slight decrease in the tangent modulus is observed after aging in seawater, whereas it remains relatively constant considering the tensile tests realised on single fibers. It is thus likely that some decohesion within the yarns may occur during aging in seawater, resulting in a slightly lower modulus for a same stress level. At the beginning of the tensile tests, the filaments would not be all oriented in the yarn direction, and would tend to orientate as stress increases.

Decohesion of Twaron 1000 yarns may be explained by the circulation of seawater in the thermostated aging tanks, and by some finish departure in seawater. Figure 10 illustrates the finish removal followed by Fourier Transformed Infrared in Attenuated Reflexion mode.

For the two aging temperatures, it appears that the finish content decreases rapidly at the beginning of aging in seawater and then stabilizes from 41 days aging onwards. After one year aging in seawater at $80^{\circ} \mathrm{C}$, the residual finish content is similar to that of Twaron 1010 fibers, for which the finish content is $0.14 \mathrm{wt} \%$.

\subsubsection{Technora T200w fibers aged in seawater}

The tensile properties of Technora T200w fibers before and after one and half years aging in seawater at $20^{\circ} \mathrm{C}$ and at $80^{\circ} \mathrm{C}$ were only measured on yarns, results are grouped in Table 3 . Valid tensile tests could not be performed on single fibers because of slippage at the tensile clamps, most probably due to the high finish content (10 to $12 \mathrm{wt} \%$ ) of Technora T200w fibers.

Here the tensile strength remains constant after one and half years aging in seawater at $20^{\circ} \mathrm{C}$, and even after the same period at $80^{\circ} \mathrm{C}$ it only decreases by around $11 \%$. This Technora fiber grade therefore appears more suitable than the Twaron grade for long-term marine immersion. For the same stress level, the tangent modulus decreases slightly after one and half years aging in seawater at $20^{\circ} \mathrm{C}$, and remains constant after one and half years aging in seawater at $80^{\circ} \mathrm{C}$ (note that at $17 \%$ of the UTS, the secant modulus decreases 
respectively by $8 \%$ and $20 \%$ for the fibers aged at 80 and $20^{\circ} \mathrm{C}$ ). As for Twaron 1000 fibers, this may be due to some decohesion within the yarns during aging.

In a similar way, decohesion of Technora T200w yarns may be explained by the circulation of seawater in the thermostated aging tanks, and by some finish departure in seawater. Figure 11 illustrates the finish removal followed by Fourier Transformed Infrared in Attenuated Reflexion mode.

It is interesting to note that in this case at $20^{\circ} \mathrm{C}$, the finish content of Technora $T 200 \mathrm{w}$ fibers decreases linearly with aging time, whereas at $80^{\circ} \mathrm{C}$, there is only a slight decrease in the finish content. It may be that at the higher temperature, crosslinking of the finish occurs.

This point must therefore be considered with caution, as details of the finish compositions are not available.

\subsection{Viscoelastic and viscoplastic properties}

\subsubsection{Comparison between Twaron 1000 and Technora T200w fibers}

Figure 12 shows the evolution of the viscoelastic and viscoplastic parameters as function of applied load for as-received Twaron 1000 fibers in comparison with Technora T200w fibers. The motor-driven system was used for these experiments.

The parameters of Twaron 1000 fibers presented here are in a similar range to those determined previously in air by Chailleux and Davies [15].

It appears that the viscoelastic and viscoplastic parameters do not follow the same trends for Twaron 1000 and Technora T200w fibers. As a general remark, it can be noted that the viscoelastic and viscoplastic parameters are more "linear" (in other words, depend less on the applied load) for the Technora T200w fibers than for the Twaron 1000 fibers.

The instantaneous compliance appears to be stable for the lower loads and tends to decrease up to $60 \%$ of the UTS for Twaron 1000 fibers, whereas it increases slightly as load increases for Technora T200w fibers. It may be pointed out that these trends are in accordance with the evolution of the tangent modulus determined from static tensile tests (Tables 2 and 3). Moreover, the creep rate of the two materials seems to diverge at higher loads. Finally, the instantaneous plasticity of Twaron 1000 fibers is lower than that of Technora T200w fibers for the lower loads. At higher loads, the instantaneous plasticity of Twaron 1000 fibers increases rapidly and becomes higher than that of Technora T200w fibers.

This difference may be partially explained in terms of deformation mechanisms. Yeh and Young [25] showed that the modulus of Twaron fibers increases continuously with strain, whereas the modulus-strain curve of Technora fibers displays two maxima around 0.3 and $2.6 \%$ strain. The authors suggested that these reductions in modulus result from molecular slippage due to less efficient lateral $\mathrm{H}$-bonds in Technora structure. These additional irreversible motions may explain the higher instantaneous plasticity of Technora fibers for lower loads, but the difference observed at higher loads still remains to be explained. 
3.2.2. Influence of seawater on the viscoelastic and viscoplastic parameters of Technora T200w fibers

Technora T200w fibers were first tested in air and in seawater (after overnight soaking) to study the influence of seawater on the viscoelastic and viscoplastic parameters. The results are presented on Figure 13. The manual loading system was used for these experiments.

The trend of decreasing instantaneous modulus (increasing g0D0) with increasing load is revealed in Figure 13-(a); this effect is accentuated when tests are performed in seawater. The creep rate is also higher, particularly at low loads (Figure 13-(b)). The irreversible strain $(\mathrm{m})$ is not affected, Figure 13-(c).

Ericksen [26] showed that the deformation of aramid fibers (PRD 49-III, Kevlar 49 and Kevlar 29) under creep is governed by the crystallite rotation; the mechanism involves shear stresses that are governed by hydrogen and van der Waals bonds in the interfibrillar regions. Wang et al. [27] carried out creep tests on Kevlar 49 filaments under equilibrium moisture conditions. They observed higher creep activation energy under low relative humidity $(5 \%)$ than under high relative humidity (95\%). To explain this behavior, they argued that the bonding force between crystallites connected by a monolayer of water molecules, formed under low relative humidity, is stronger than that between crystallites connected by a multilayer of water molecules, formed under high relative humidity.

It is likely that multilayers of water molecules are formed under immersion in seawater. It may explain the higher instantaneous compliance observed for the higher load levels (from $\sim 30 \%$ of the ultimate tensile strength). The water molecules may favour the instantaneous crystallite rotation by weakening the hydrogen bonds between the crystallites, resulting in a lower instantaneous modulus. In a similar way, the penetration of seawater into the structure may explain the higher creep rates.

\subsubsection{Influence of aging on the viscoelastic and viscoplastic parameters of aramid fibers}

\section{Twaron 1000 fibers}

In order to simulate the influence of longer immersions both Twaron and Technora fibers were then subjected to creep-recovery cycles after prolonged aging. Given that the tests described above had shown an effect of the test environment, all subsequent tests were performed in seawater.

Figure 14 shows the influence of an 18-month aging period in seawater at $20^{\circ} \mathrm{C}$ on the behavior of Twaron 1000 fibers.

In Figure 14-(a) the increasing stiffness at higher load level is apparent, with lower stiffness at low loads for the aged samples. Creep rates at low loads are also lower after aging, while the irreversible strain is again unaffected.

At the lower loads, the instantaneous modulus is lower for Twaron 1000 fibers aged in seawater. And yet, it has been shown from tensile tests performed on single fibers that the tensile modulus remains constant after one and half years aging in seawater at $20^{\circ} \mathrm{C}$ (Table 2). The decrease in the instantaneous modulus observed here may result from decohesion of the filaments in the yarn, which is probably favoured by finish removal in seawater. Indeed, the tensile tests performed at the yarn scale reveal a slight decrease $(\sim 11 \%)$ in the tangent modulus measured at $20 \%$ of the ultimate tensile strength accompanied by a decrease in the finish content above $65 \%$, after one and half years aging in seawater at $20^{\circ} \mathrm{C}$. As for the 
tensile tests, it is likely that the filaments are not all aligned in the yarn direction at the beginning of the creep-recovery tensile test and may orientate with increasing load. The strain involved in this process may be included in the low load creep rates calculation.

\section{Technora T200w fibers}

Figure 15 shows the influence of aging in seawater at 20 and $80^{\circ} \mathrm{C}$ on the behavior of Technora T200w yarns.

The main effect noted here is a drop in initial stiffness (by about $20 \%$ ) after aging at $80^{\circ} \mathrm{C}$. This may be again due to decohesion of the fibers in the yarn in the aging tanks and then on the horizontal test frame. Re-tensioning the yarn during loading on the creep test bed at low loads brings the fibers back to their initial state, and at higher loads there is no longer an influence of aging on the different parameters. This "structural strain" removal may then appear as an apparent permanent strain, and results in a vertical offset of all the values of $\mathrm{m}$ for the aged samples (Figure 15-(c)). As the Technora T200w could not be tested at the unitary fiber scale, the inherent mechanical properties could not be measured independently of this "yarn effect". Further work is thus required to confirm these interpretations.

The viscoelastic and viscoplastic parameters of Technora T200w fibers aged at $20^{\circ} \mathrm{C}$ determined for the lower load also need to be confirmed, as only one point is available in these conditions.

\section{Conclusions}

This paper presents results from a study of the influence of seawater aging on the mechanical behavior of two grades of aramid fibers, Twaron 1000 and Technora T200w.

Static tensile tests indicate up to $20 \%$ reductions in strength after one and half years in seawater at $20^{\circ} \mathrm{C}$ but little change in modulus. These fibers appear well-suited to marine applications but further work is needed to quantify their long-term durability in seawater.

An automated creep-recovery procedure has been developed, enabling the parameters for a non-linear viscoelastic-viscoplastic model to be identified between $17 \%$ and $60 \%$ of the ultimate tensile strength.

First, it is shown that the Technora T200w and Twaron 1000 fibers behave differently in creep-recovery tests. The most striking difference concerns the instantaneous compliance: it is stable for the lower loads and tends to decrease up to $60 \%$ of the UTS for Twaron 1000 fibers, whereas it increases slightly as load increases for Technora T200w fibers, which is in accordance with static tensile tests.

This work reveals a significant influence of the tests condition for Technora T200w fibers. The creep rate and instantaneous compliance are higher when the tests are performed in seawater, most probably due to a weakening of lateral $\mathrm{H}$-bonds which would favour the crystallites rotation. The determination of the viscoelastic and viscoplastic parameters in seawater is thus necessary to predict the long-term creep-recovery behavior of aramid fibers for marine applications.

Finally, the influence of aging in seawater on the parameters is not evident from the tests performed here. The slight differences observed for aged samples may result from yarn decohesion that occurs during aging. Even though the aging results in a significant reduction 
of the static tensile strength, the viscoelastic and viscoplastic behavior within the load range studied here are not strongly affected after prolonged immersion in a seawater environment.

\section{References}

1. P.G. Riewald, AICHE Symposium Series, 76, 133 (1980).

2. H.H. Yang, Aromatic high strength, Wiley-Interscience (1989).

3. H.H. Yang, Kevlar Aramid Fiber, John Wiley \& Sons (1993).

4. M.G. Dobb, D.J. Johnson and B.P. Saville, J. Polym. Sci.: Polym. Symp. , 58 , 237 (1977).

5. M.G. Dobb, D.J. Johnson and B.P. Saville, J. Polym. Sci. , Part B: Polym. Phys. , 15 , 2201 (1977).

6. H. Imuro and N. Yoshida, $25^{\text {th }}$ International Man Made Fibers Congress, Dornbirn, 1 (1986).

7. L.-S. Li, L.F. Allard and W.C. Bigelow, J. Macromol. Sci. , Part B: Phys. , 22 , 269 (1983).

8. R.J. Morgan, C.O. Pruneda and W.J. Steele, J. Polym. Sci. , Part B: Polym. Phys. , 21 , 1757 (1983).

9. M. Panar, P. Avakian, R.C. Blume, K.H. Gardner, T.D. Gierke and H.H. Yang, J. Polym. Sci. , Part B: Polym. Phys. , 21 , 1955 (1983).

10. M.G. Northolt and J.J. van Aartsen, J. Polym. Sci.: Polym. Symp. , 58 , 283 (1977).

11. M.G. Northolt, Polymer, 21 , 1199 (1980).

12. M.G. Northolt, J.J.M. Baltussen and B. Schaffers-Korff, Polymer, 36 , 3485 (1995).

13. M.G. Northolt and R. van der Hout, Polymer, 26 , 310 (1985).

14. J.J.M. Baltussen and M.G. Northolt, Polymer, 42 , 3835 (2001).

15. E. Chailleux and P. Davies, Mechanics of Time-Dependent Materials, 7 , 291 (2003).

16. J.J.M. Baltussen and M.G. Northolt, Polymer, 40 , 6113 (1999).

17. Y. Lou and R.A. Schapery, Journal of Composite Materials, 5 , 208 (1971).

18. R.A. Schapery, Mechanics of Time-Dependent Materials, 1 , 209 (1997).

19. P. Perzyna, Advances in Applied Mechanics, 243 (1966).

20. M.H. Lafitte and A.R. Bunsell, Polym. Eng. Sci. , 25 , 182 (1985).

21. J. Lai and A. Bakker, Polym. Eng. Sci. , 35,1339 (1995).

22. G. Derombise, L. Vouyovitch Van Schoors and P. Davies, J. Appl. Polym. Sci. , 116 , 2504 (2010). 
23. G. Derombise, L. Vouyovitch Van Schoors, M.-F. Messou and P. Davies, accepted for publication in J. Appl. Polym. Sci.

24. G. Derombise, L. Vouyovitch Van Schoors and P. Davies, Polym. Degrad. Stab. , 94 , 1615 (2009).

25. W.-Y. Yeh and R.J. Young, Polymer, 40 , 857 (1999).

26. R.H. Ericksen, Polymer, 26 , 733 (1985).

27. J. Wang, D. Dillard and T. Ward, J. Polym. Sci. , Part B: Polym. Phys. , 30 , 1391 (1992). 


$$
\text { copoly(paraphenylene/3,4'-oxydiphenylene terephthalamide) (Technora }(\mathbb{R})
$$

Figure 1: Aramid molecular structures [2,3]

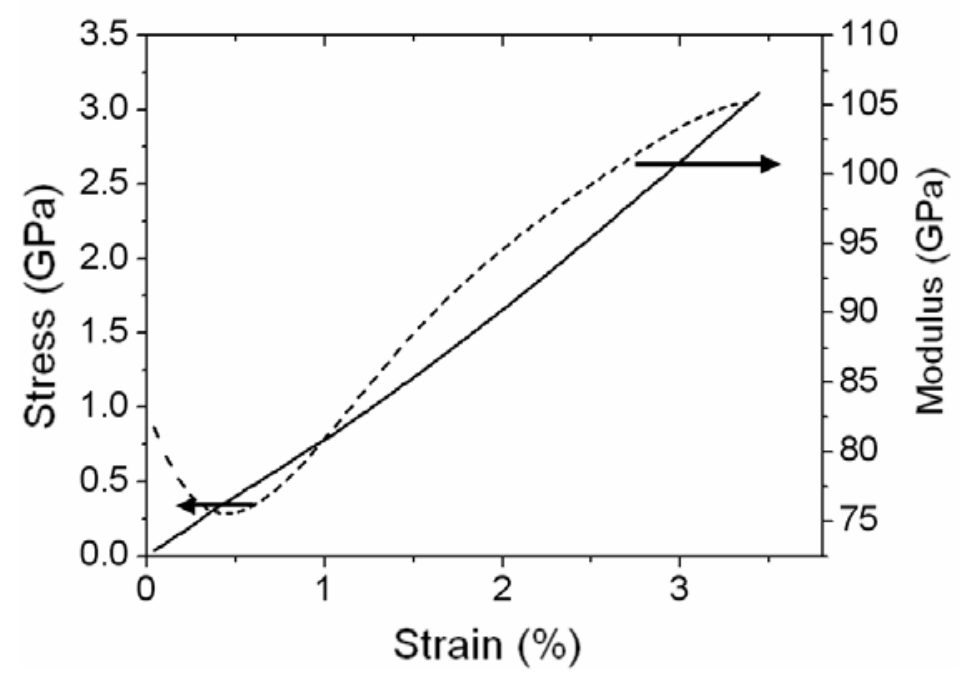

Figure 2: Stress-strain and modulus-strain curves of Twaron 1000 single fiber

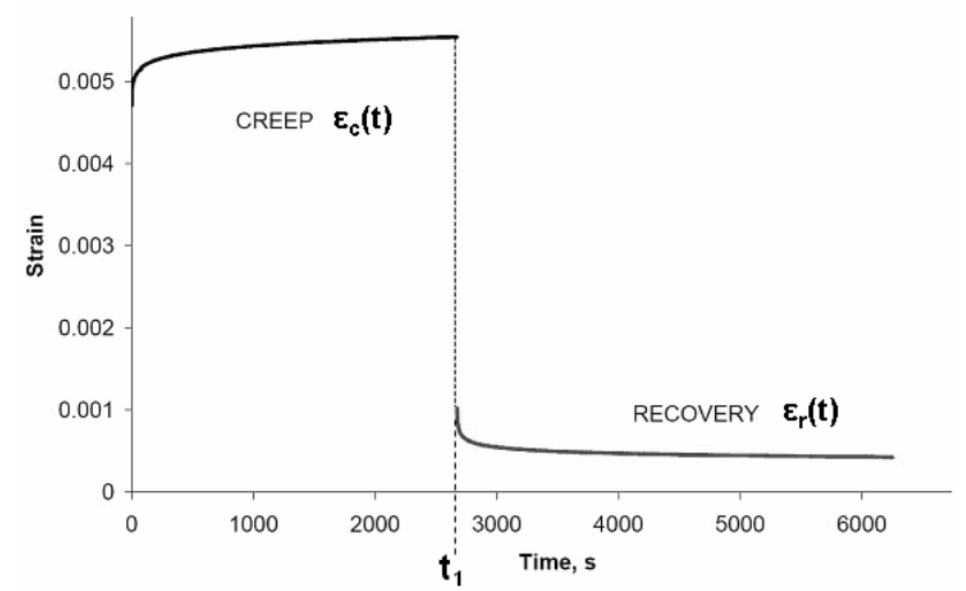

Figure 3: Example of a creep-recovery curve of a Twaron 1000 yarn. $\varepsilon_{c}(t)$ and $\varepsilon_{r}(t)$ represent the creep strain and the recovery strain at a time $t$, respectively. 


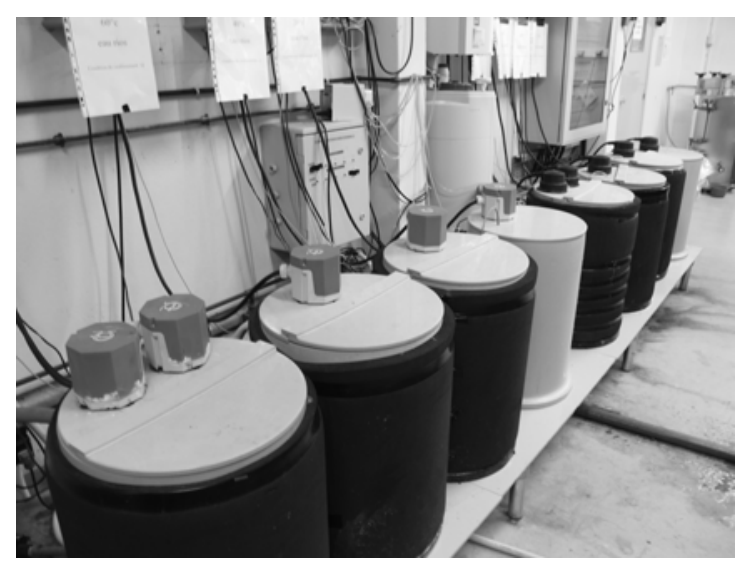

Figure 4: Temperature controlled circulating sea water tanks

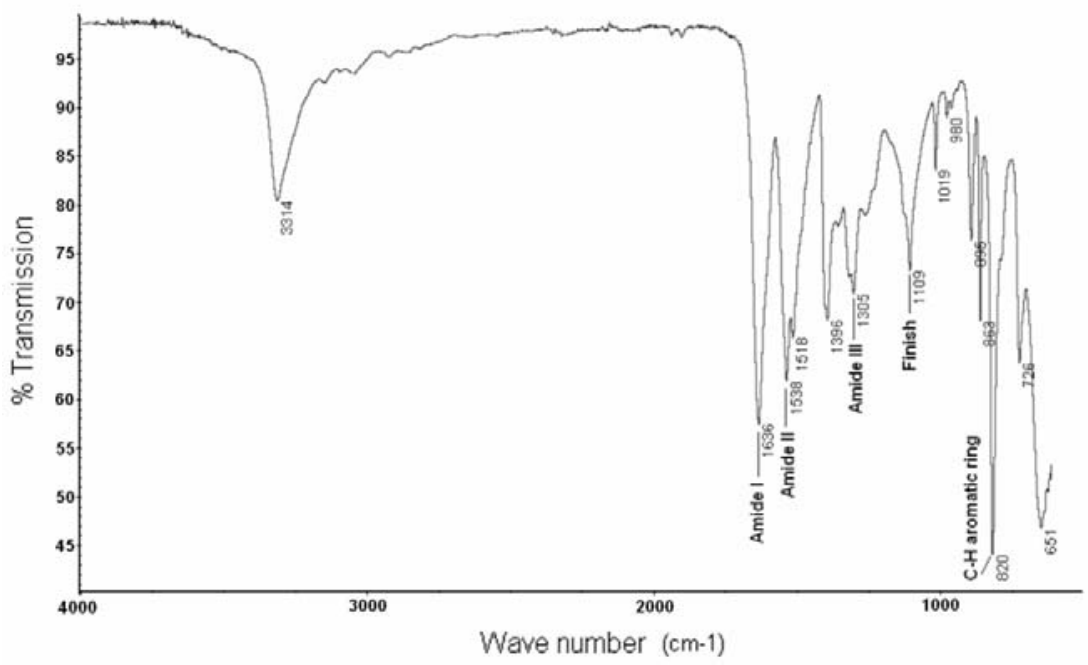

Figure 5: FTIR spectrum of as-received Twaron 1000 fibers

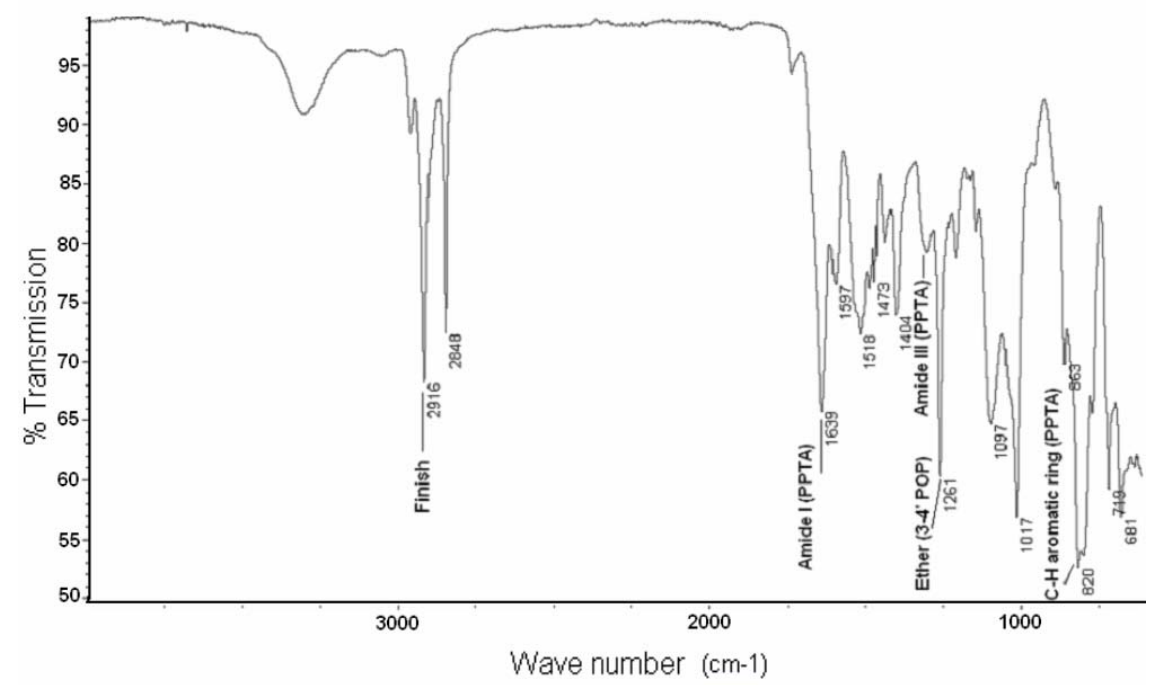

Figure 6: FTIR spectrum of as-received Technora T200w fibers 


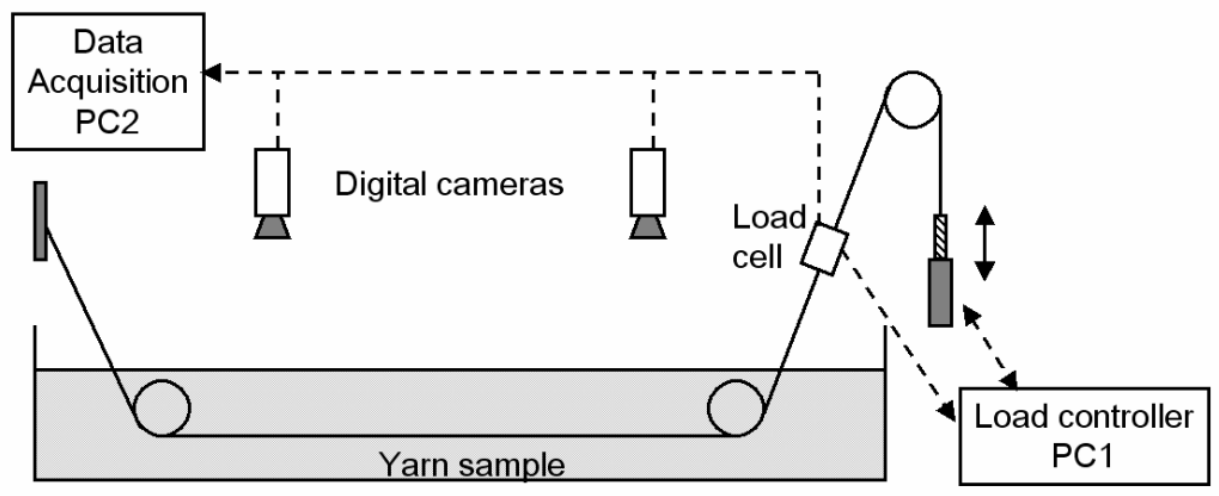

Figure 7: Creep-recovery system

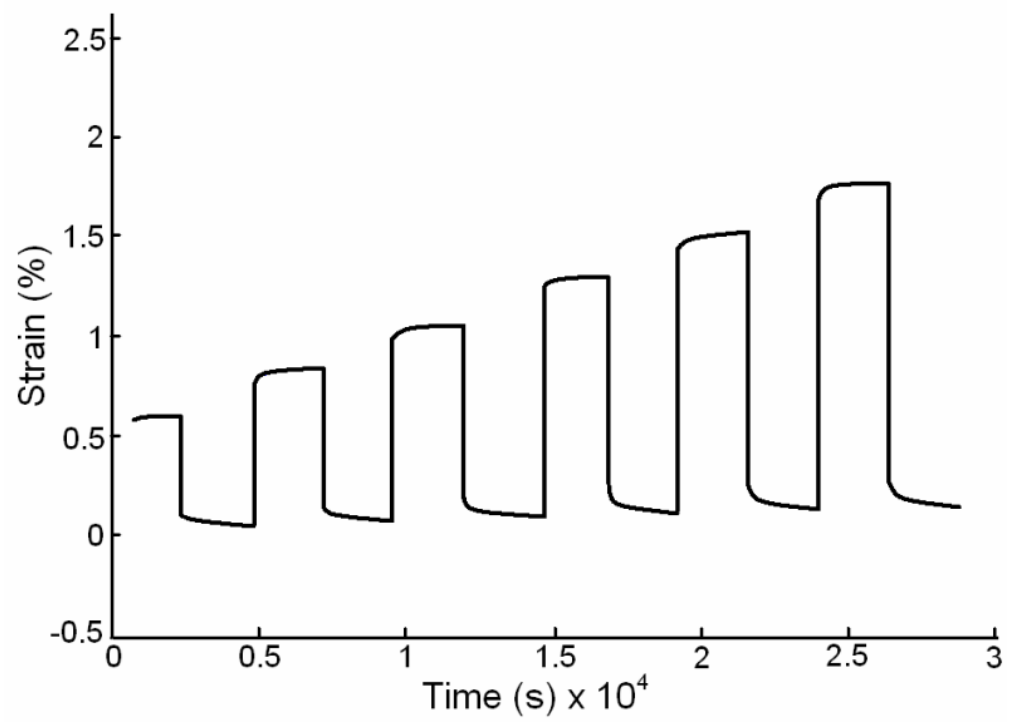

Figure 8: Example of creep-recovery strain versus time recording

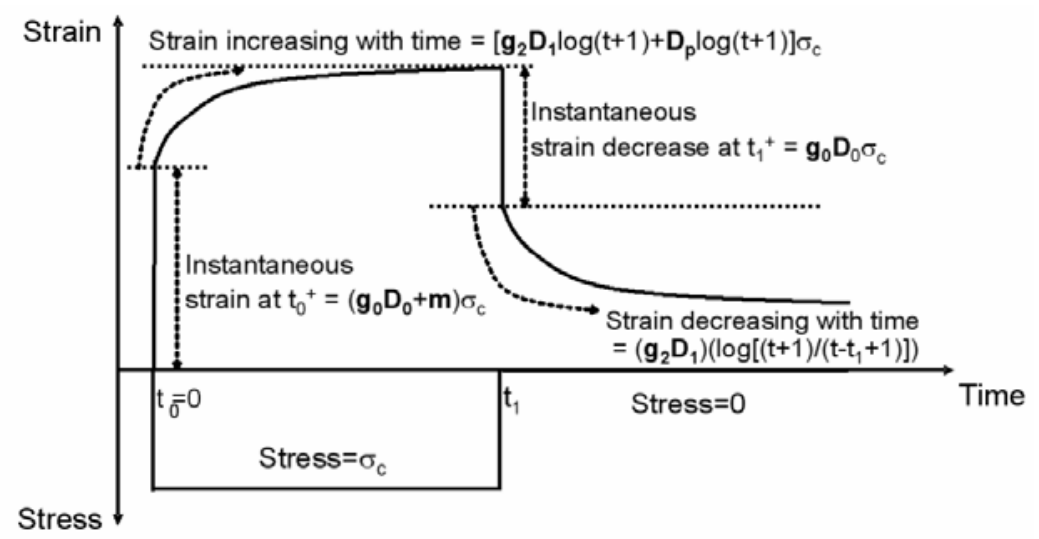

Figure 9: Description of the viscoelastic and viscoplastic parameters in a creep-recovery experiment 


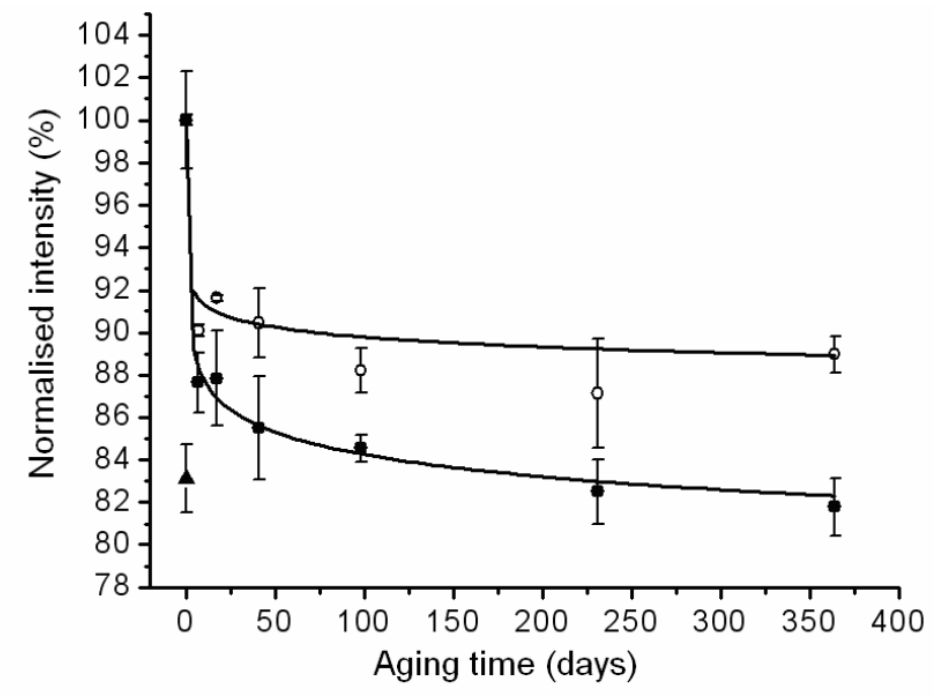

- Twaron 1000 -sea water, $20^{\circ} \mathrm{C}$

- Twaron 1000-sea water, $80^{\circ} \mathrm{C}$

- Twaron 1010-as received

Figure 10: Evolution of the normalised intensity of the FTIR peak related to the finish of Twaron 1000 fibers

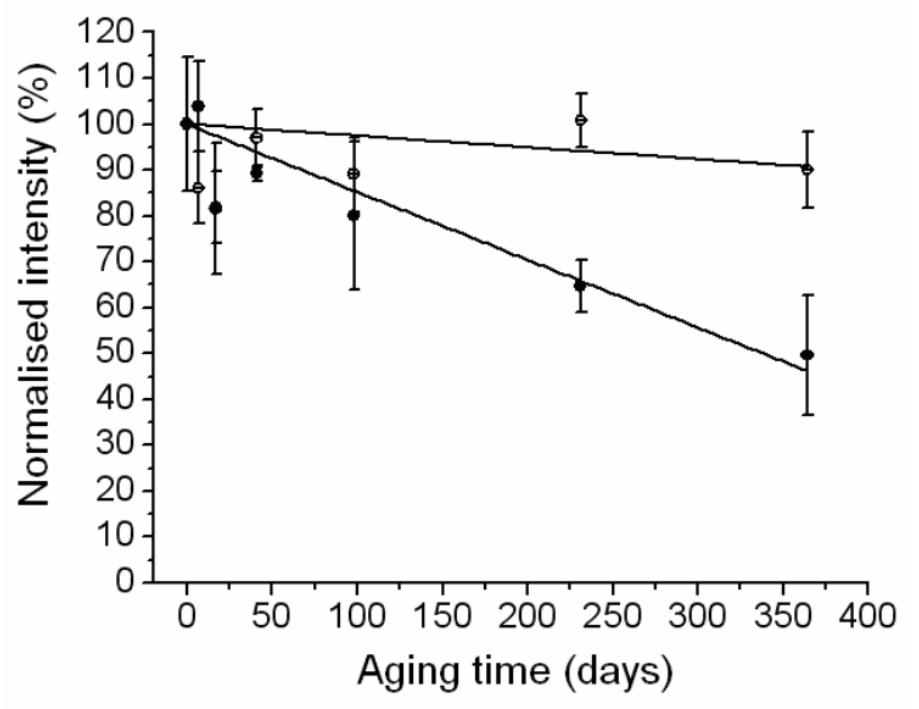

- T200w-sea water, $80^{\circ} \mathrm{C}$

- T200w-sea water, $20^{\circ} \mathrm{C}$

Figure 11: Evolution of the normalised intensity of the FTIR peak related to the finish of Technora T200w fibers 


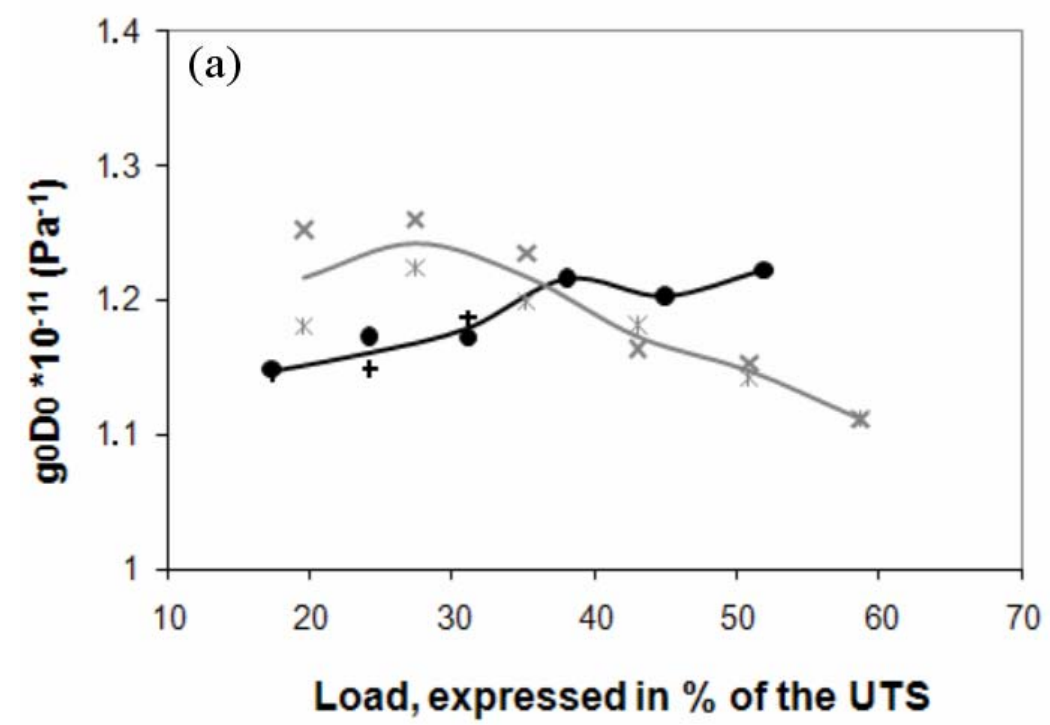

- T200w as-received, $\mathrm{N}^{\circ} 1 \quad \times \mathrm{T} 1000$ as-received, $\mathrm{N}^{\circ} 1$

+ T200w as-received, $\mathrm{N}^{\circ} 2 \quad *$ T1000 as-received, $\mathrm{N}^{\circ} 2$

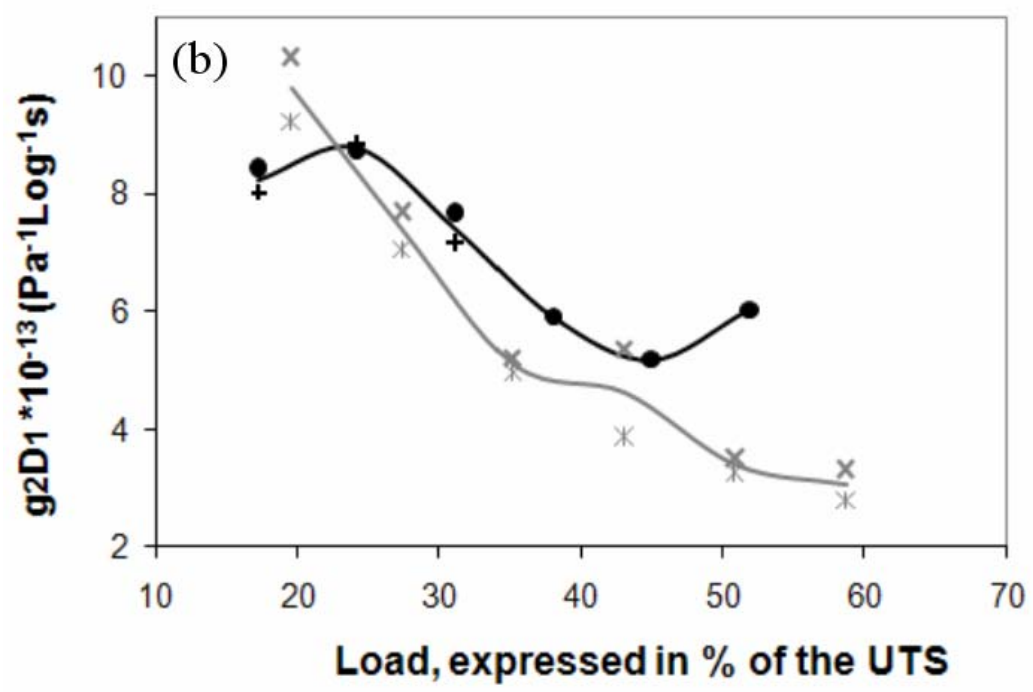

- T200w as-received, $\mathrm{N}^{\circ} 1 \quad \times \mathrm{T} 1000$ as-received, $\mathrm{N}^{\circ} 1$

+ T200w as-received, $\mathrm{N}^{\circ} 2 \quad *$ T1000 as-received, $\mathrm{N}^{\circ} 2$ 


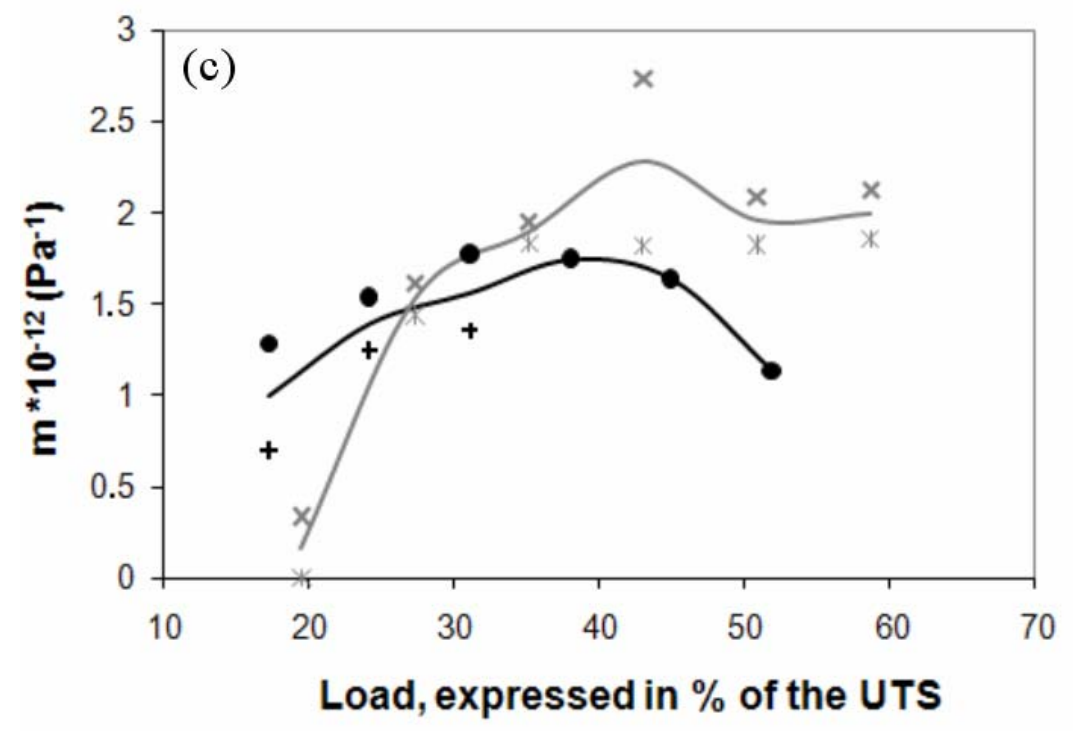

- T200w as-received, $\mathrm{N}^{\circ} 1$

$\times \mathrm{T} 1000$ as-received, $\mathrm{N}^{\circ} 1$

+ T200w as-received, $\mathrm{N}^{\circ} 2$

$* \mathrm{~T} 1000$ as-received, $\mathrm{N}^{\circ} 2$

Figure 12: Viscoelastic and viscoplastic parameters (a) g0D0, (b) g1D2 and (c) m, in seawater at ambient temperature, using the motor-driven loading system. The lines connect the average values. 


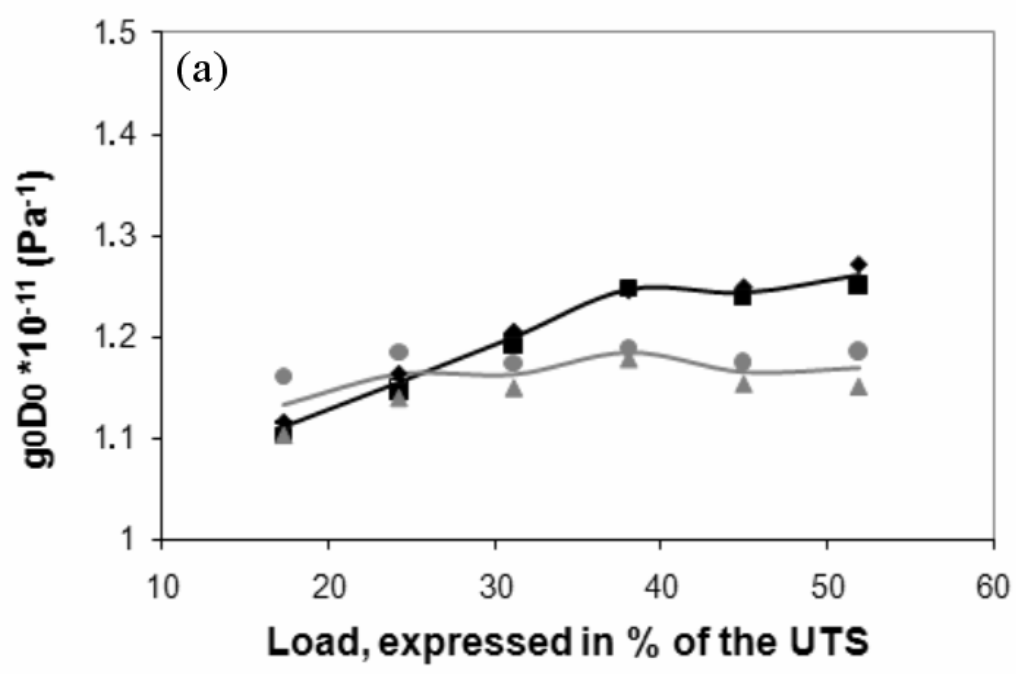

- T200w as-received, sea water, $N^{\circ} 1 \quad$ T200w as-received, air, $N^{\circ} 1$

- T200w as-received, sea water, $\mathrm{N}^{\circ} 2 \quad \Delta$ T200w as-received, air, $\mathrm{N}^{\circ} 2$

-T200w as-received, sea water, $\mathrm{N}^{\circ} 3$

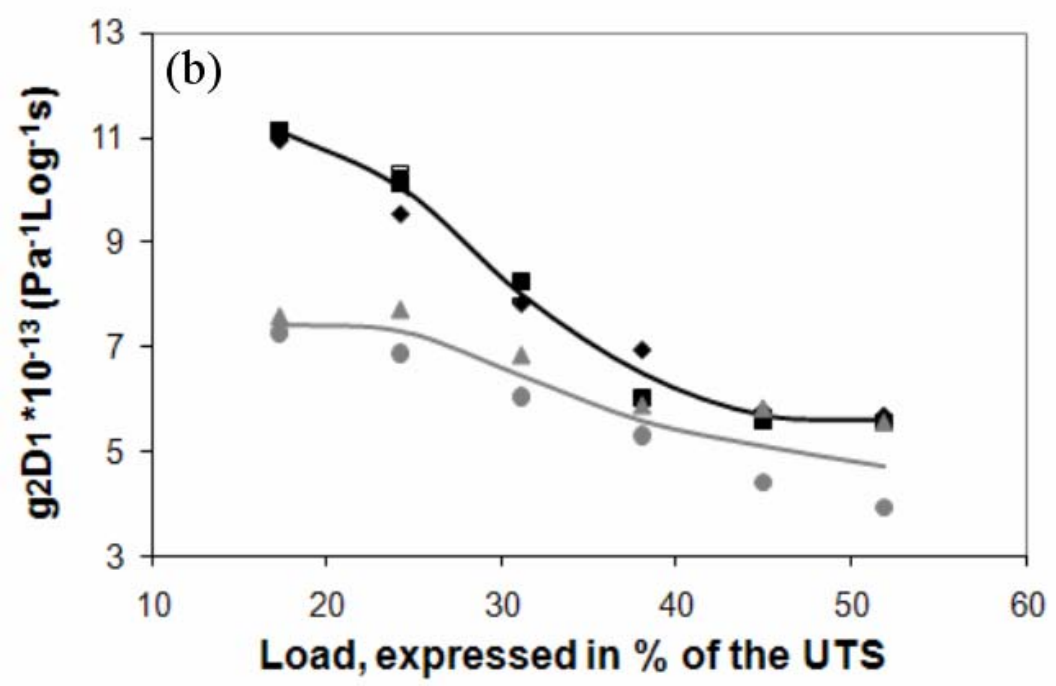

- T200w as-received, sea water, $N^{\circ} 1 \quad$ T200w as-received, air, $N^{\circ} 1$

- T200w as-received, sea water, $\mathrm{N}^{\circ} 2 \quad \Delta$ T200w as-received, air, $\mathrm{N}^{\circ} 2$

-T200w as-received, sea water, $\mathrm{N}^{\circ} 3$ 


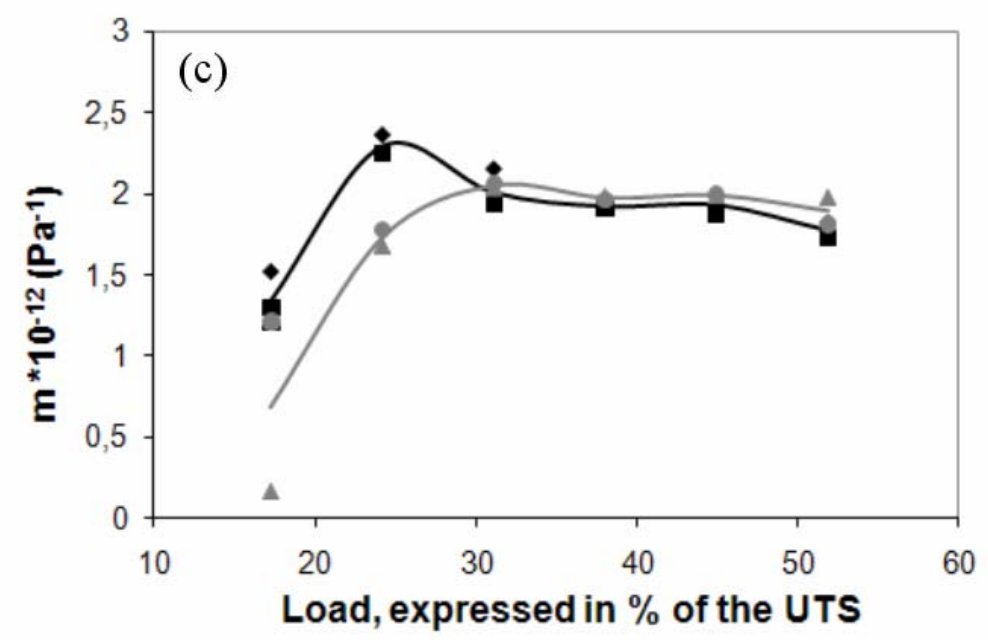

- T200w as-received, sea water, $N^{\circ} 1$

- T200w as-received, air, $N^{\circ} 1$

- T200w as-received, sea water, $\mathrm{N}^{\circ} 2 \quad \Delta$ T200w as-received, air, $\mathrm{N}^{\circ} 2$

- T200w as-received, sea water, $\mathrm{N}^{\circ} 3$

Figure 13: Viscoelastic and viscoplastic parameters (a) g0D0, (b) g1D2 and (c) m, in air and in seawater at ambient temperature, using the manual loading system. The lines connect the average values.

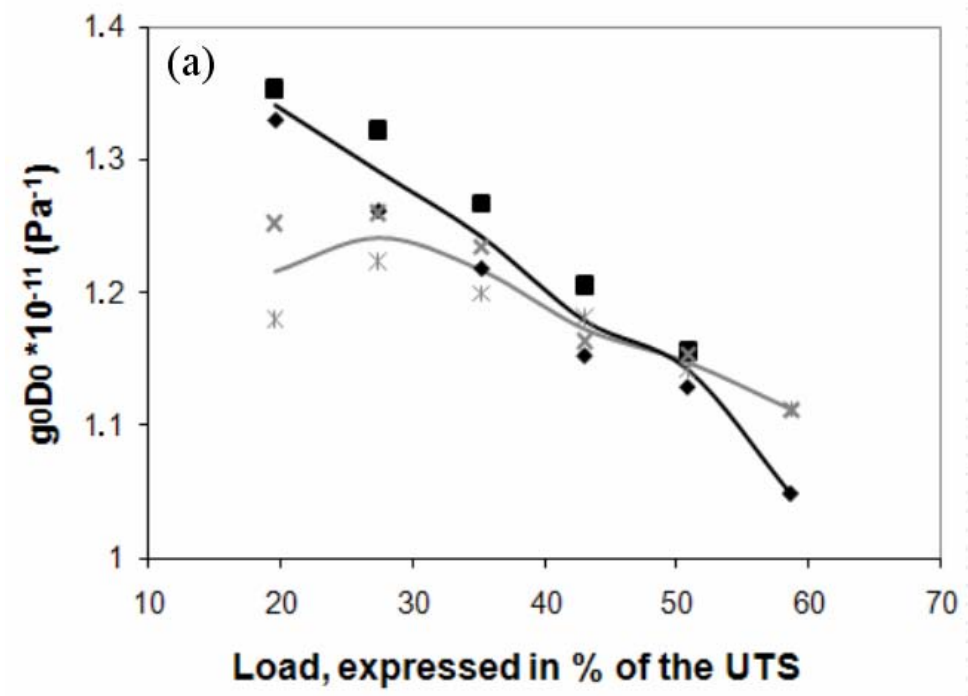

- T1000 - sea water, $20^{\circ} \mathrm{C}, 549$ days, $\mathrm{N}^{\circ} 1 \quad \times \mathrm{T} 1000$ as-received, $\mathrm{N}^{\circ} 1$

-T1000 - sea water, $20^{\circ} \mathrm{C}, 549$ days, $\mathrm{N}^{\circ} 2 \quad * \mathrm{~T} 1000$ as-received, $\mathrm{N}^{\circ} 2$ 


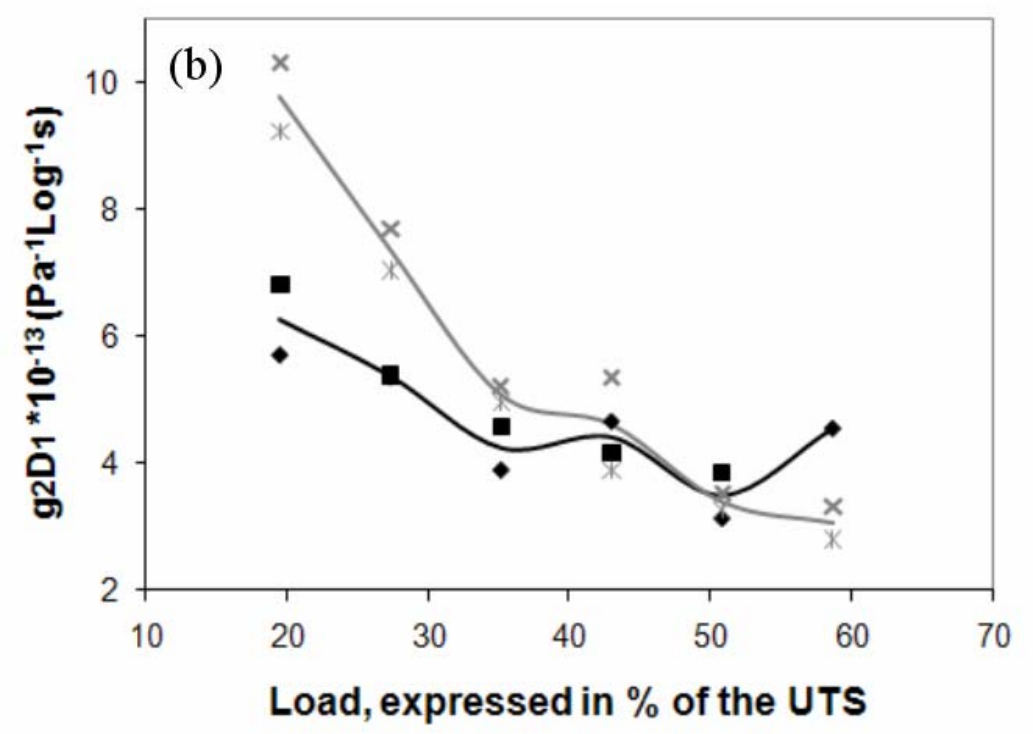

- T1000 - sea water, $20^{\circ} \mathrm{C}, 549$ days, $\mathrm{N}^{\circ} 1 \quad \times \mathrm{T} 1000$ as-received, $\mathrm{N}^{\circ} 1$

- T1000 - sea water, $20^{\circ} \mathrm{C}, 549$ days, $\mathrm{N}^{\circ} 2 \quad * \mathrm{~T} 1000$ as-received, $\mathrm{N}^{\circ} 2$

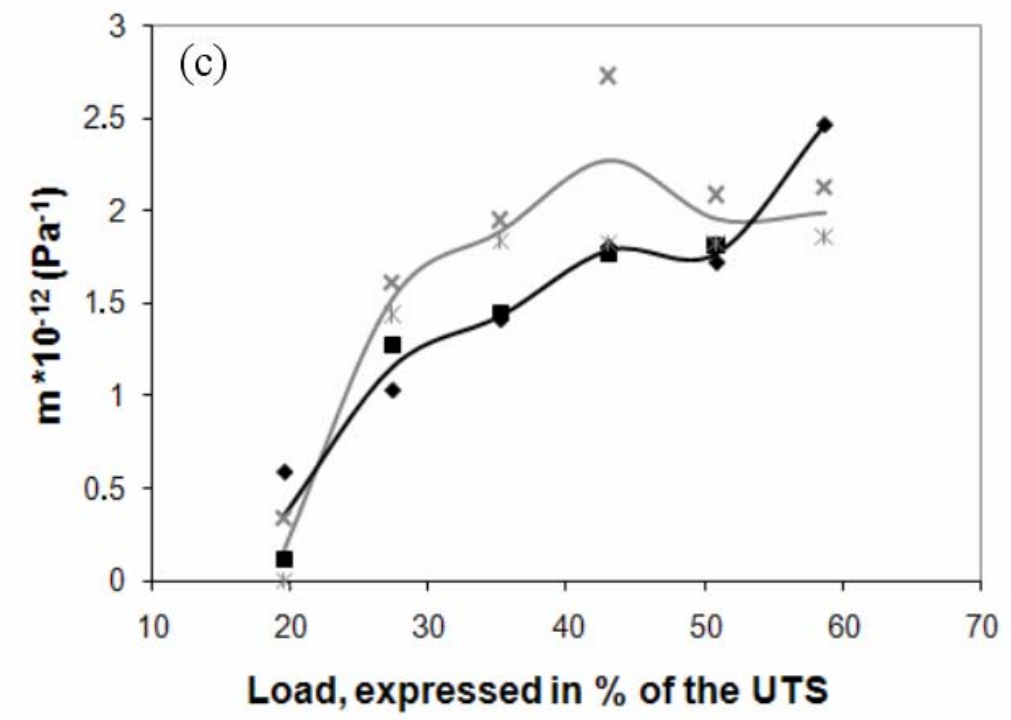

- T1000 - sea water, $20^{\circ} \mathrm{C}, 549$ days, $\mathrm{N}^{\circ} 1 \quad \times \mathrm{T} 1000$ as-received, $\mathrm{N}^{\circ} 1$

- T1000 - sea water, $20^{\circ} \mathrm{C}, 549$ days, $\mathrm{N}^{\circ} 2 \quad * \mathrm{~T} 1000$ as-received, $\mathrm{N}^{\circ} 2$

Figure 14: Viscoelastic and viscoplastic parameters (a) g0D0, (b) g1D2 and (c) m of Twaron 1000 yarns as-received and aged in sea water. The tests were performed in sea water at ambient temperature, using the motor-driven loading system. The lines connect the average values. 


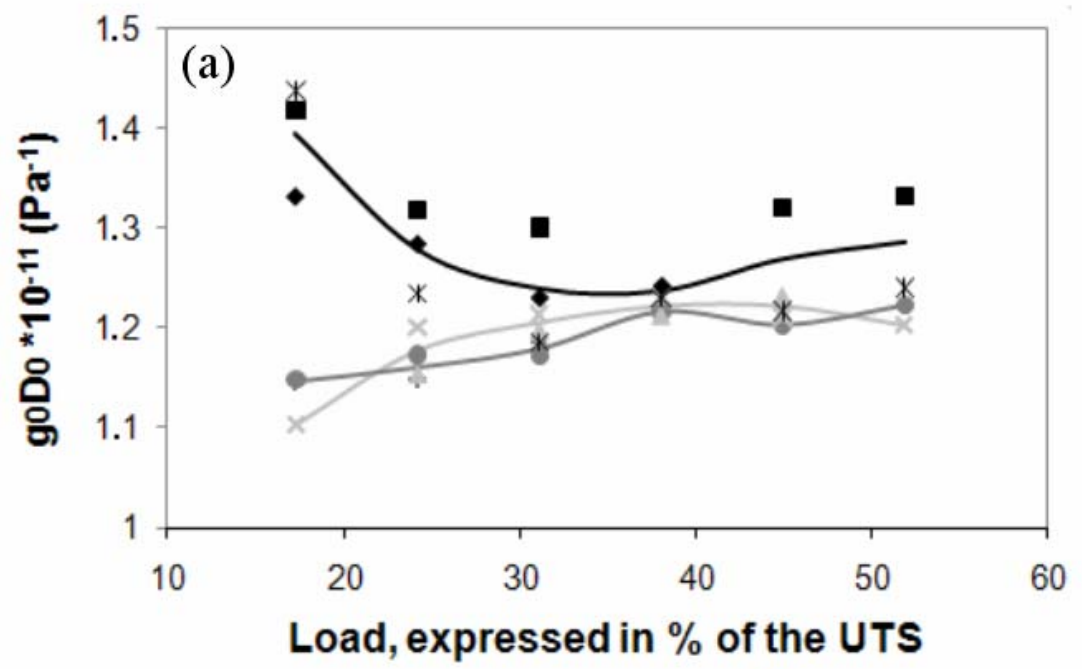

$\triangle \mathrm{T} 200 \mathrm{w}$ - sea water, $20^{\circ} \mathrm{C}, 549$ days, $\mathrm{N}^{\circ} 1 \quad$ T200w as-received, $\mathrm{N}^{\circ} 1$ $\times$ T200w - sea water, $20^{\circ} \mathrm{C}, 549$ days, $\mathrm{N}^{\circ} 2+$ T200w as-received, $\mathrm{N}^{\circ} 2$

- T200w - sea water, $80^{\circ} \mathrm{C}, 549$ days, $\mathrm{N}^{\circ} 1$

- T200w - sea water, $80^{\circ} \mathrm{C}, 549$ days, $\mathrm{N}^{\circ} 2$

* T200w - sea water, $80^{\circ} \mathrm{C}, 549$ days, $\mathrm{N}^{\circ} 3$

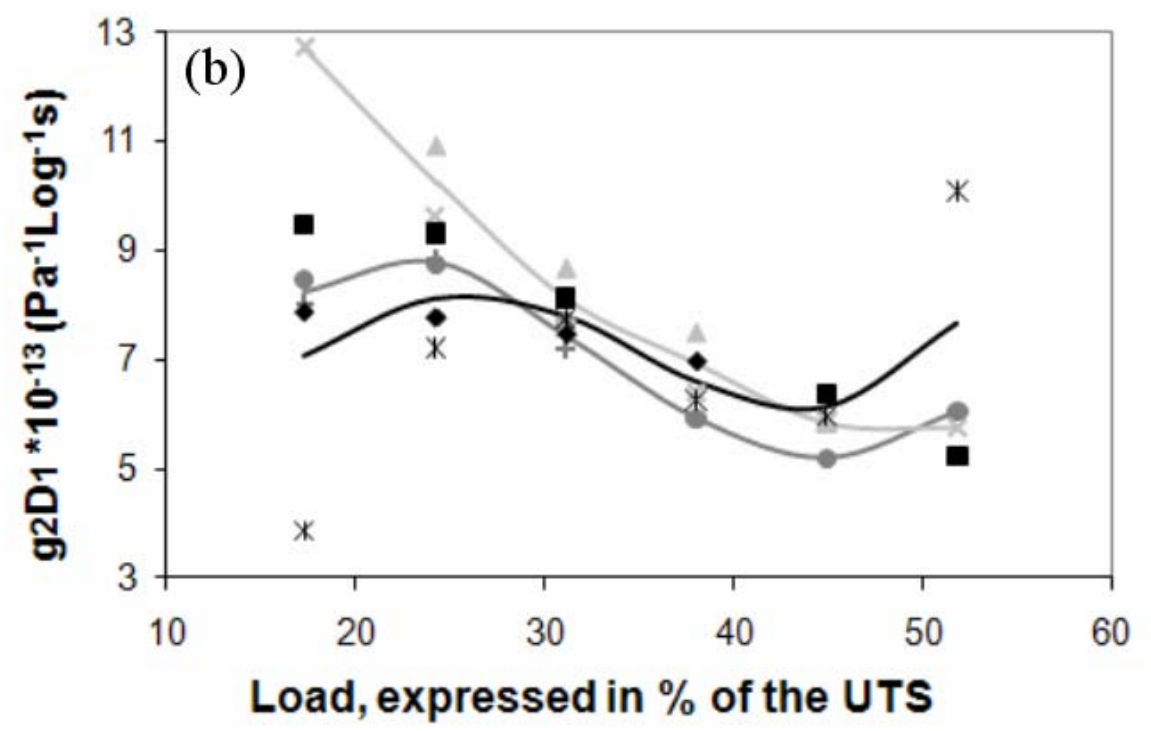

$\triangle$ T200w - sea water, $20^{\circ} \mathrm{C}, 549$ days, $\mathrm{N}^{\circ} 1-\mathrm{T} 200 \mathrm{w}$ as-received, $\mathrm{N}^{\circ} 1$

$\times$ T200w - sea water, $20^{\circ} \mathrm{C}, 549$ days, $\mathrm{N}^{\circ} 2+\mathrm{T} 200 \mathrm{w}$ as-received, $\mathrm{N}^{\circ} 2$

- T200w - sea water, $80^{\circ} \mathrm{C}, 549$ days, $\mathrm{N}^{\circ} 1$

- T200w - sea water, $80^{\circ} \mathrm{C}, 549$ days, $\mathrm{N}^{\circ} 2$

$* \mathrm{~T} 200 \mathrm{w}$ - sea water, $80^{\circ} \mathrm{C}, 549$ days, $\mathrm{N}^{\circ} 3$ 


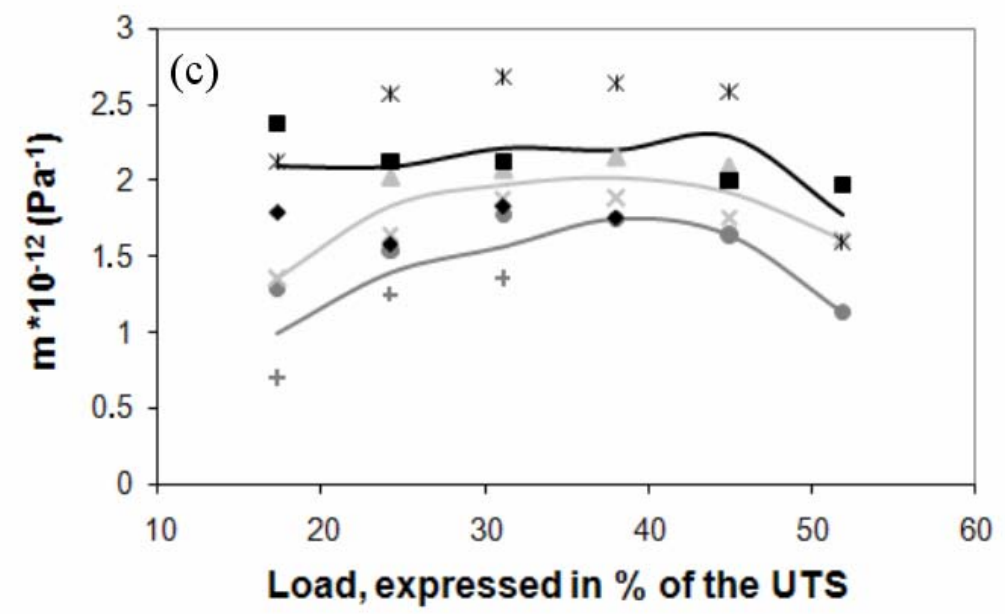

$\triangle \mathrm{T} 200 \mathrm{w}$ - sea water, $20^{\circ} \mathrm{C}, 549$ days, $\mathrm{N}^{\circ} 1 \quad-\mathrm{T} 200 \mathrm{w}$ as-received, $\mathrm{N}^{\circ} 1$

$\times$ T200w - sea water, $20^{\circ} \mathrm{C}, 549$ days, $\mathrm{N}^{\circ} 2+$ T200w as-received, $\mathrm{N}^{\circ} 2$

- T200w - sea water, $80^{\circ} \mathrm{C}, 549$ days, $\mathrm{N}^{\circ} 1$

- T200w - sea water, $80^{\circ} \mathrm{C}, 549$ days, $\mathrm{N}^{\circ} 2$

* T200w - sea water, $80^{\circ} \mathrm{C}, 549$ days, $\mathrm{N}^{\circ} 3$

Figure 15: Viscoelastic and viscoplastic parameters (a) g0D0, (b) g1D2 and (c) $m$ of Technora T200w yarns as-received and aged in sea water. The tests were performed in sea water at ambient temperature, using the loading-unloading motor-driven system. The lines connect the average values. 